\title{
Education for All: Are the Doors of Learning Opened for All in the Provision of Quality Education in South Africa?
}

\author{
Takalani Samuel Mashau \\ Humbulani Nancy Mutshaeni \\ Lufuno Reginald Kone
}

University of Venda P/Bag x5050 Thohoyandou 0950

takalani.mashau@univen.ac.za \& nancy.mutshaeni@univen.ac.za

Doi:10.5901/mjss.2014.v5n23p1285

\begin{abstract}
The quest to achieve Education for All (EFA) is fundamentally about assuring that children, youth and adults gain the knowledge and skills they need to better their lives and to play a role in building more peaceful and equitable societies. It is therefore imperative to focus on quality in order to achieve EFA. As many societies strive to universalise basic education, they face the momentous challenge of providing conditions where genuine learning can take place for each and every learner. The six goals adopted at the World Education Forum in Dakar, Senegal, in April 2000, implicitly or explicitly integrate a quality dimension. Goal 6, in particular, commits countries, with the support of their EFA partners, to improve all aspects of the quality of education. The benefits of early childhood, literacy and life-skills programmes largely depend on the quality of their contents and of their teachers. The conceptual paper aims at analysing whether South Africa will meet the goals of Education for All in 2015 which are part of Millennium Development Goals (MGD). The question to be asked is: "Is South Africa going to meet goals of Education for All in the provision of quality education?"
\end{abstract}

Keywords: Education for All; quality education; early childhood education; compulsory education.

\section{Inroduction}

The six goals adopted at the World Education Forum in Dakar, Senegal, in April 2000, implicitly or explicitly integrate a quality dimension. Goal 6 , in particular, commits countries, with the support of their EFA partners, to improve all aspects of the quality of education. The benefits of early childhood, literacy and life-skills programmes largely depend on the quality of their contents and of their teachers. Reducing gender disparities in education relies strongly on strategies that address inequalities in the classroom and in society. Primary and secondary education - the central planks of most education systems-are expected to ensure that all pupils acquire the knowledge, skills and values necessary for the exercise of responsible citizenship (UNESCO, 2004).

\section{International Declarations}

Bray (2002:31) indicates that, during the first four decades after Second World War, the dominant feature of international pronouncements concerning education was that public education should be free of charge, especially at the basic education level. In this section international declarations which contribute towards the provision of basic education will be discussed.

According to Bray (2002 p. 31) Article 26 of the 1948 United Nation Declaration of Human Rights states that:

- Everyone has the right to education.

- Education shall be free, at least in the elementary and fundamental stages.

Bray (2002 p. 31) points out that, later, the 1959 Declaration on the Rights of the Child stated that:

- The child is entitled to receive education, which shall be free and compulsory at least in the early stages.

Also, Article 13 of the 1966 International Covenant on Economics, Social and Cultural Rights declared that:

- Primary education shall be compulsory and free to all.

- Secondary education in its different forms, including technical and vocational secondary education, shall be made generally available and accessible to all by every appropriate means, and in particular by the 
progressive introduction of free education. Higher education shall be made equally accessible to all, on the basis of capacity, by every appropriate means, and in particular by the progressive introduction of free education.

However, Article 28 of 1989 Convention on the Rights of the Child brought about a subtle shift in such thinking. The Convention indicates that signatory states would:

- Make primary education compulsory and available free to all.

- Encourage the development of different forms of secondary education and make them available to every child, and to this end to take appropriate measures such as the introduction of free education and offering of financial assistance in the case of need; and make higher education accessible to all on the basis of capacity, by every appropriate means.

The aims of education, from the Convention on the Rights of the Child, Article 29 (1) states Parties agree that the education of the child shall be directed to:

- The development of the child's personality, talents and mental and physical abilities to their fullest potential;

- The development of respect for human rights and fundamental freedoms, and for the principles enshrined in the Charter of the United Nations;

- The development of respect for the child's parents, his or her own cultural identity, language and values, for the national values of the country in which the child is living, the country from which he or she may originate, and for civilizations different from his or her own;

- The preparation of the child for responsible life in a free society, in the spirit of understanding, peace, tolerance, equality of sexes, and friendship among all peoples, ethnic, national and religious groups and persons of indigenous origin; and

- The development of respect for the natural environment.

On the same note, Brighouse (1998 p. 140) indicates that states fund education in order to provide equal opportunity, so that those who are at the same level of talent and ability and have the same willingness to use them should have the same prospects of success, regardless of their initial place in the social system-that is, irrespective of the income, the state should grant equal educational opportunities.

Educational opportunities provide two distinct kinds of good. They provide:

- Competitive advantages in economies which distribute benefits and burdens unequally. More educational opportunities of a certain kind enhance prospective lifetime income and job satisfaction. Non-competitive opportunities for fulfilling life experiences. This includes not only the reward of executing excellently those tasks which demand the skills one has learned, but also the rewards which result from entertaining, executing, and reflecting on those tasks in a social context.

According to Watkins (2000 p. 10), accelerated progress towards Education for All depends critically upon what happens at the national level. Governments need to mobilize the resources required for achieving universal education, and they need strategies for overcoming the huge equity gaps, the parameters of which are determined by income, gender, religion and ethnicity.

Watkins (2000 p. 10-11) further argues that, under the Dakar Framework of 2000 Education for All, states are expected to establish clear budget priorities for education. There are no blueprints for public investment. However, in countries where a large proportion of the primary school population does not complete primary education, the aim should be to invest at least $3 \%$ of the GDP on basic education-a level that few countries currently achieve. The Dakar Framework of 2000 also calls on governments to identify strategies for reducing inequalities in education, especially those related to gender. Once again, there are no blueprints. National strategies need to take into account local realities and to build on partnerships between governments, non-governmental organizations, and local communities.

\section{Broad Principles that Should Guide National Plans of Governments}

Following are the broad principles which should guide plans of the governments in the provision of quality education according to Watkins (2000):

- End charges for basic education

No child should be excluded from education because of the poverty of his or her family. States should establish timetables for eliminating direct and indirect fees.

- Integrating education into national poverty-reduction strategies

Poverty remains the main obstacle to achieving education for all. This is therefore the reason why education 
reforms are integrated into anti-poverty strategies that are in turn institutionalized in macro-economic reform programmes. Equally important is participation in the development of national education strategies.

- Building on existing education-sector strategies

National plans should define clear targets for accelerating progress towards universal primary education, along with the funding gaps to be filled through increased aid under global initiatives. The objective should be to shorten the time-frame for achieving education for all, with an immediate focus on universal primary education.

- Improving the quality of education

Adapting the curriculum to local needs, adjusting the school calendar to local circumstances (such as seasonal labour demands), teaching in local languages, and improving training and support for educators are among the most important requirements.

- Involving parents and local communities

The real experts in understanding why poor children do not go to school, or why they drop out, are the poor themselves. National education planning should include a far stronger commitment to involving the poor in education, both in assessing the problems and in identifying the solutions.

\section{Education for All (EFA) Goals}

Six: Education for All goals will be discussed in the following paragraphs:

Goal 1: Expand early childhood care and education

Progress towards wider access of early childhood care and education (ECCE) remains slow, with children from disadvantaged backgrounds are more likely to be excluded from ECCE. A child in sub-Saharan Africa can expect only 0.3 years of pre-primary schooling, compared to 1.6 years in Latin America and the Caribbean and 2.3 years in North America and Western Europe. In many developing countries, ECCE programmes are staffed by teachers with low qualifications.

\section{Goal 2: Provide free and compulsory primary education for all}

Ensure that, by 2015 , children everywhere, boys and girls alike, will be able to complete a full course of primary schooling. The number of out-of-school children is declining, having fallen from 106.9 million in 1998 to 103.5 million in 2001. While progress has been made globally, over the past decade, in getting more children into school, the pace remains too slow to achieve UPE by 2015. If past trends continue, the world net enrolment ratio was about $85 \%$ in 2005 and $87 \%$ in 2015. Completion of primary schooling remains a major concern: delayed enrolment is widespread, survival rates to grade 5 are low (below $75 \%$ in thirty of ninety-one countries for which data are available) and grade repetition is frequent.

Goal 3: Promote learning and life skills for young people and adults: Eliminate gender disparity in primary and secondary education, preferably by 2005 , and in all levels of education

Efforts to raise the level of skills among youths and adults are marginal in the few developing countries that have conducted evaluations of skills development programmes. Progress remains difficult to assess on a global basis.

Goal 4: Increase adult literacy by 50 per cent

About 800 million adults were illiterate in 2002; $70 \%$ of them live in nine countries belonging mostly to sub-Saharan Africa and East and South Asia, notably India, China, Bangladesh and Pakistan.

\section{Goal 5: Achieve gender parity by 2005, gender equality by 2015}

Although many countries around the world have made significant progress towards gender parity at primary and secondary levels over the past decade, large gaps remain, particularly in the Arab States, sub-Saharan Africa and South and West Asia. Girls accounted for $57 \%$ of the out-of-school children of primary school age worldwide in 2001 and for more than $60 \%$ in the Arab States and in South and West Asia. Girls' participation remains substantially lower than boys' (a gender parity index below 0.97 ) in seventy one out of 175 countries at primary level. Gender disparities become more extreme at secondary level and in higher education. Of eighty-three developing countries with data, half have achieved gender parity at primary level, fewer than one-fifth at secondary and only four at tertiary. Almost two-thirds of the world's adult illiterates (64\%) are women.

Goal 6: Improve the quality of education

Countries that are farthest from achieving goals 1 to 5 are also farthest from achieving goal 6 . Several indicators provide information on dimensions of quality. Public expenditure on education represents a higher proportion of GDP in rich countries, where the EFA goals are already achieved, than in poorer ones, where the coverage of under-resourced systems needs to be both expanded and improved. Spending has increased over the past decade in many developing countries, notably in East Asia and the Pacific and in Latin America and the Caribbean. Pupil/teacher ratios remain higher 
than is desirable in many countries of sub-Saharan Africa (regional median: 44:1) and South and West Asia (40 p. 1). In many low-income countries, teachers do not meet even the minimum standards for entry into teaching and many have not fully mastered the curriculum. The HIVIAIDS pandemic is severely undermining the provision of good education and contributing significantly to teacher absenteeism. Data from national and international test scores show that low achievement is widespread in most developing regions (UNESCO, 2004 p. 16 and Narayan, 2012 p. 4).

\section{Better Quality Education for All}

Better quality education is attributed by the UNESCO (2004 p. 17) where challenge, definition of quality, benefits of education, years of learners in school, test scores, resources and coordination are discussed as follows:

The challenge: Education for all cannot be achieved without improving quality. In many parts of the world, an enormous gap persists between the numbers of students graduating from school and those among them who master a minimum set of cognitive skills. Any policy aimed at pushing net enrolments towards $100 \%$ must also assure decent learning conditions and opportunities.

Defining quality: Two principles characterise most attempts to define quality in education: the first identifies learners' cognitive development as the major explicit objective of all education systems. Accordingly, the success with which systems achieve this is one indicator of their quality. The second emphasises education's role in promoting values and attitudes of responsible citizenship and in nurturing creative and emotional development. The achievement of these objectives is more difficult to assess and compare across countries.

Benefits: Better education contributes to higher lifetime earnings and more robust national economic growth, and helps individuals make more informed choices about fertility and other matters important to their welfare. For example, it reduces exposure to HIVIAIDS: research shows that cognitive gains from basic education are the most important factor in protecting teenagers from infection. Such benefits are closely linked to the education levels achieved.

Years in school: Higher quality in education improves school life expectancy, though opportunities differ widely by region. On average for all countries, pupils can expect 9.2 years of primary plus secondary education; a child in subSaharan Africa, however, can expect to receive five to six fewer years of schooling than one in Western Europe and the Americas. People in countries with the highest levels of school life expectancy can expect to stay in school up to five times as long as those in countries at the bottom of the range.

Test scores: International achievement tests reveal that socio-economic status has a strong influence on levels of school outcomes. Both educational and economic policies need to address initial and ongoing socio-economic inequalities among learners.

Resources: In low-income countries, increasing spending to provide more textbooks, reduce class size and improve teacher education and school facilities has a positive impact on learners' cognitive achievement, though the relationship is weaker in richer countries where overall standards of provision are much higher. Improvements in quality can often be achieved at modest cost and are within reach even in the poorest countries. Where repetition rates in schools are very high, modest increases in quality can be partly self-financing because they reduce the length of time pupils take to complete the cycle.

Coordination: Stronger links among government departments responsible for early childhood care and education, literacy and health can help improve quality. In addition, gender-sensitive policies in education and broadly-based gender reforms in society can directly improve the quality of education.

\section{South African EFA Perspective}

Milner \& Khoza (2008 p. 155) state that it is widely acknowledged that the provision of quality education in South African schools is one of the greatest challenges facing South Africa in the $21^{\text {st }}$ century. A skilled, and sophisticated workforce is a prerequisite to competing in today's global, technology driven economic environment and education is key to developing such a workforce.

The Table below indicates that 5023110 youths in South Africa are not attending any type of educational institution. In a country where skills are scares and such a number of youths are out of wilderness, this creates a sense of concern. 
Table 1: Among persons aged 5-24 years, whether or not they were attending an educational institution, and if so type of institution, by province (number)-Census 2011.

\begin{tabular}{|c|c|c|c|c|c|c|c|c|c|c|}
\hline Educational institution & WC & EC & NC & FS & KZN & NW & GP & MP & LP & SA \\
\hline Not Attending & 601519 & 588802 & 128332 & 270629 & 1060805 & 369806 & 1170802 & 403321 & 429095 & 5023110 \\
\hline Attending & 1221232 & 2040311 & 289812 & 736002 & 3020720 & 880621 & 2616530 & 1195535 & 1837198 & 13837961 \\
\hline Pre-schools & 18813 & 10866 & 2437 & 9212 & 15885 & 8613 & 45770 & 7586 & 9538 & 128719 \\
\hline Schools & 1105619 & 1964641 & 279929 & 683207 & 2845161 & 831276 & 2242167 & 1147485 & 1763478 & 12862961 \\
\hline Colleges & 35383 & 27386 & 4150 & 18318 & 64632 & 17495 & 131757 & 23638 & 36469 & 359228 \\
\hline \begin{tabular}{|l|} 
Universityl \\
Technikon
\end{tabular} & 54931 & 28334 & 1710 & 21508 & 76464 & 18290 & 177556 & 11426 & 19846 & 410063 \\
\hline ABET & 1567 & 2304 & 322 & 1425 & 4193 & 2197 & 7365 & 1555 & 2827 & 23756 \\
\hline $\begin{array}{l}\text { Home based } \\
\text { education }\end{array}$ & 5337 & 7185 & 1342 & 2508 & 15236 & 2973 & 12749 & 4136 & 5392 & 56857 \\
\hline Total & 1822751 & 262911 & 18144 & 00663 & 408152 & 25042 & 3787332 & 59885 & 266293 & 18861071 \\
\hline
\end{tabular}

According to National Development Plan (2011 p. 268) great strides have been made. Access to education at various levels has been improved and race and gender disparities have been largely eliminated.

- In $199622.5 \%$ of five year olds were enrolled in an early childhood development institutions. In $200780.7 \%$ were enrolled.

- Universal excess and gender parity were almost achieved in schooling by 2010. About $99 \%$ complete grades 1-9.

- Since 1996, the numbers of schools without water has decreased from 9000 to 1700 and a number of schools without electricity has dropped from 15000 to 2800 . The percentage of classrooms with more than 45 learners has decreased from $55 \%$ to $25 \%$.

- School funding policy has been pro-poor resulting in $60 \%$ of schools to be "no fee" schools.

- National nutrition programme feeds about 16 million children in 18000 schools across the country.

Despite many positive changes since 1994, the legacy of low-quality education in historically disadvantaged parts of the school system still persists. This seriously hampers the education system's ability to provide a way out of poverty of poor children. Learners in these schools typically exhibit low proficiency in reading, writing and numeracy.

Two factors are largely responsible for the failings of the school system. The primary cause is weak capacity through the civil service-teachers, principals, and system level-officials which results not only to poor schools outcomes but also breeds a lack of respect to government. The mirror image of this weakness in the technical core is a culture of patronage that permeates almost all areas of the civil service. Nepotism and the appointment of unsuitable personnel further weaken government capacity (National Development Plan, 2011).

\subsection{Expansion of early childhood care and education}

According to Global Monitoring Report (2008) it is discouraging to note that ECE programmes for young children under the age of 3 remain largely neglected. Services for young children in South Africa are on the brink of transformation as the country is developing its first national Early Childhood Development (ECD) policy and strengthening its ECD policy and legislative framework. The essays in this issue of the South African Child Gauge have outlined critical conceptual shifts that should inform short to medium-term planning. This should result in significant improvements in the delivery of an essential package of ECD services to a large number of young children who are currently not receiving support (Albino and Berry, 2013). This is an indication that South Africa is still on the way to reach EFA goals as far as expansion of early childhood care and education. It might be beyond 2015.

After certain considerations South Africa would not reach the target by 2015 in this regard, or the country to reach EFA goals, in order to improve the quality of learning the quality of children's learning experiences in the foundation phase needs urgent attention. Specifically:

- Develop and support foundation phase teachers by improving their content knowledge and numeracy and literacy teaching strategies;

- Clearly conceptualise the role of grade $\mathrm{R}$ and its relationship to prior early learning and formal education;

- Increase attention to young children's physical and psychological well-being by securing the nutrition, health, safe transport and after-school care of children in the foundation phase (Albino and Berry, 2013). 


\subsection{Provide free and compulsory primary education for all}

According to Tomaševski (2001) promises fall into oblivion, highlighting the importance of human rights law which defines individual rights and the corresponding governmental obligations. Human rights law requires rights to be precisely defined so that they can be effectively claimed, their violations exposed, remedied, and prevented, so that people would have effective means for holding their governments accountable.

The introduction of South African Schools Act of 1996 has introduced compulsory attendance for learners. In 2014 $96 \%$ of schools are no fee schools. In this regard it is interesting to find out that South Africa is going to reach target of offering free and compulsory education for all in 2015.

\subsection{Gender equality}

African countries have shown good overall progress in gender equality and the empowerment of women in recent years. The ratio of girls to boys in primary education is approaching parity in almost every country, and the proportion of women in African national parliaments continued its upward trend in 2010. Gender equality is a constitutional imperative in South Africa. The government has therefore introduced a range of policies, laws, programs and mechanisms that specifically address the needs of women and girls (Global Monitoring Report, 2011).

Altogether, South Africa has performed so well that the country has reached most of the MDG gender-related targets. Of course, there is still room for improvement, especially in the area of violence against women. Nevertheless it can be concluded that South Africa remains committed to tackling gender inequality.

\subsection{Improve the quality of education}

Quality education remains elusive as schools are deprived of resources, facilities and qualified teachers, as the Department of Basic Education has also acknowledged. It is hard to imagine efficiency, effectiveness and quality in education developing under these circumstances. The quality of education therefore needs to be improved at the primary and secondary level so that the system prepares individuals for the demands of higher education (Jones, 2014).

Jones (2014) goes further to indicate that with high enrolment rates in the South African schooling system, the environment is now conducive for the department to pursue interventions to improve the quality of education. Although some initiatives are already under way, the challenge remains the implementation and practice of these interventions. The department acknowledges that the South African schooling system is characterised by major weaknessesparticularly in relation to the quality of education provision and the poor learning outcomes. It is the quality of education that would play a "fundamental role" in achieving the six goals, and much work needs to be done to ensure that this is provided.

\section{Conclusions}

South Africa like most other countries in the world will never reach Education for All Goals in totality except two goals which are gender parity and free and compulsory education. According to International Education (2014) both the Millennium Development Goals and the Education for All goals should be met in 2015, but by now it is known that none of the goals will be met by their deadline if current trends continue. With 2015 around the corner, the discussions about what should come next have started, and the United Nations is leading the process of agreeing on a new development agenda.

With considerable progress that remains to be made and the deadline around the corner, the international community has shifted its focus towards a post-2015 development agenda. The MDGs are expected to be replaced by a new and universal agenda for poverty eradication and sustainable development. The process is coordinated by the United Nations (UN) but the new agenda will ultimately be designed and decided upon by the UN member states at the UN General Assembly in 2015 International Education (2014).

Over the past year, a number of different processes have informed these debates, such as surveys and global consultations, expert committees and the UN High-Level Panel. Currently the main processes are the Open Working Group on Sustainable Development Goals and the Intergovernmental Committee of Experts on Sustainable Development Financing. Both these processes come out of the Rio+20 Conference on Sustainable Development, held in 2012, in Rio de Janeiro, Brazil, and are expected to report to the 2014 UN General Assembly.

The doors of learning in South Africa are opened. The doors of learning are opened, unfortunately there is no 
quality education; quality education remains elusive as schools are deprived of resources, facilities and qualified teachers. It is hard to imagine efficiency, effectiveness and quality in education under these circumstances.

\section{References}

Albino, N \& Berry, L. (2013). Early childhood development services in South Africa: What are the next steps? Paris: UNESCO.

Bray, M. (2002). The costs and financing of education. In Bray, M. (ed). The costs of financing education: Trends and policy implication. Education in developing Asia, Vol. 3.Hong Kong: Asian Development Bank/ University of Hong Kong.

Brighouse, H. (1998). Why should state fund schools? British journal of educational studies. 46(2):138-152.

Education International. (2014). Post-2015 Development Agenda: Make Quality Education a Priority! www.ei-ie.org/en/websections/ content_detail/7226. [Access Date 30 June 2014].

Jone, M. (2014). Education quality 'needs to be improved'. IOL News. 30 January 2014.

Milner, K. \& Khoza, H. (2008) .A comparison of teacher stress and school climate across schools with different matric success rates. South African Journal of Education. Vol. 28 (2): 155-173.

South Africa. National Development Plan. (2011). www.npconline.co.za/medialib. [Accesses Date: 18 October 2013].

Narayan, S. (2012). Education for All: Beyond 2015-Mapping Current International Actions to Define the Post-2015 Education and Development Agendas. Paris: UNESCO.

Tomaševski, K. (2001). Free and compulsory education for all children: the gap between promise and performance. Gothenburg: Novum Grafiska AB.

UNESCO. (2004). Education for All: the quality imperative. Paris: UNESCO.

Watkins, K. (2000). The Oxfam education report. England: Oxfam. 